\title{
Media Sosial Sebagai Media Promosi Kesehatan
}

\author{
Shofura Nida Khansa, Muhammad Ali Sodik
}

IIK STRADA INDONESIA

\section{shofuranida@gmail.com, alisodik2012@gmail.com}

\begin{abstract}
Abstrak
Media sosial memiliki ciri khas tertentu dalam kaitannya pada manusia yaitu merupakan salah satu platform yang muncul di media siber. Promosi kesehatan adalah proses mengupayakan individu individu dan masyarakat untuk meningkatkan kemampuan mereka mengandalkan faktor-faktor yang mempengaruhi kesehatan sehingga dapat meningkatkan derajat kesehatannya. Situs web media sosial yang populer terbukti efektif dan ampuh untuk menyebarluaskan informasi kesehatan, mendukung upaya promosi kesehatan dan dapat ditelusuri secara online seperti YouTube, Facebook, Twitter, blog, dll.
\end{abstract}

Kata Kunci : Informasi kesehatan, media social, masyarakat, promosi kesehatan

\section{Latar Belakang}

Media sosial merupakan medium internet yang memungkinkan penggunannya mempresentasikan dirinya maupun berinteraksi, bekerjasama, saling berbagi, berkomunikasi dengan pengguna lainnya dan membentuk ikatan sosial secara virtual. Media sosial dalam ranah kekinian merupakan sebuah era barudalam hal sarana komunikasi yang semakin intensif dalam pemanfaatan kemajuan teknologi. Media sosial memiliki efektifitas untuk digunakan sebagai media promosi kesehatan. Efektifitas yang dipaparkan merupakan hasil-hasil penelitian yang menggunakan atau memanfaatkan media sosial dalam bidang kesehatan, baik media sosial sebagai bahan subtansi maupun sarana. Permasalahan kesehatan di Indonesia saat ini yaitu masih rendahnya kesadaran kaum milenial tentang menggunakan media sosial sebagai alat promosi kesehatan.

\section{Rumusan Masalah}

Permasalahan kesehatan di Indonesia saat ini yaitu masih rendahnya kesadaran kaum milenial tentang menggunakan media sosial sebagai alat promosi kesehatan. Banyak yang di dapat dari media sosial mengenai kesehatan masyarakat. Berdasarkan uraian latar belakang tersebut, maka dapat dirumuskan pertanyaan penelitian "Bagaimana peran sarjana kesahatan masyarakat melakukan promosi kesehatan berbasis media sosial pada kaum milenial?"

\section{Tinjauan Pustaka}

Definisi lain dari sosial media juga di jelaskan oleh Van Dijk, media social adalah platform media yang memfokuskan pada eksistensi pengguna yang memfasilitasi mereka 
dalam beraktivitas maupun berkolaborasi. Karena itu, media sosial dapat dilihat sebagai fasilitator online yang menguatkan hubungan antar pengguna sekaligus sebagai sebuah ikatan social (Thea, 2016).

Menurut WHO, promosi kesehatan adalah proses mengupayakan individu individu dan masyarakat untuk meningkatkan kemampuan mereka dengan mengandal kan faktor-faktor yang mempengaruhi kesehatan sehingga dapat meningkatkan derajat kesehatannya. Sedangkan Indonesia merumuskan pengertian promosi kesehatan adalah upaya untuk meningkatkan kemampuan masyarakat melalui pembelajaran dari, oleh, untuk dan bersama masyarakat agar mereka dapat menolong dirinya sendiri (mandiri) serta mengembangkan kegiatan bersumber daya masyarakat sesuai sosial budaya setempat dan didukung oleh kebijakan publik yang berwawasan kesehatan.

\section{Pembahasan}

Media sosial adalah sebuah media online, dengan para penggunanya bias dengan mudah berpartisipasi, berbagi, dan menciptakan isi meliputi blog, jejaring sosial, wiki, forum dan dunia virtual. Blog, jejaring sosial dan wiki merupakan bentuk media sosial yang paling umum digunakan oleh masyarakat di seluruh dunia. Pendapat lain mengatakan bahwa media sosial adalah media online yang mendukung interaksi sosial dan media sosial menggunakan teknologi berbasis web yang mengubah komunikasi menjadi dialog interaktif.

Jadi, media sosial adalah media online yang mendukung interaksi sosial.Sosial media menggunakan teknologi berbasis web yang mengubah komunikasi menjadi dialog interaktif. Beberapa situs media sosial yang populer sekarang iniantara lain : Blog, Twitter, Facebook, Instagram, Path, dan Wikipedia.

Keputusan Menteri Kesehatan Nomor 1114 /MENKES/SK/VII/2005 tentang Pedoman Pelaksanaan Promosi Kesehatan di Daerah, promosi kesehatan adalah upaya untuk meningkatkan kemampuan masyarakat melalui pembelajaran bersama masyarakat, agar mereka dapat menolong diri sendiri, serta mengembangkan kegiatan yang bersumber daya masyarakat, sesuai social budaya setempat dan didukung kebijakan publik yang berwawasan kesehatan (Kemenkes, 2011).

Era digital yang dikenal dengan Web 2.0 atau Health 2.0 atau Medicine 2.0 menjadikan masyarakat sehat dan pasien lebih mengandalkan internet daripada dokter sebagai sumber informasi perawatan kesehatan. Situs web media social yang populer terbukti efektif dan ampuh untuk menyebarluaskan informasi kesehatan, mendukung upaya promosi kesehatan dan dapat ditelusuri secara online seperti YouTube, Facebook, MySpace, Twitter, dan Second Life serta image sharing, mobile technology dan blog.

Seorang sarjana kesehatan masyarakat dapat melakukan kegiatan promosi kesehatan pada masyarakat untuk meningkatkan kesadaran pola hidup sehat dalam kehidupan sehari-hari melalui media Twitter, Facebook, Instagram, Youtube yang berisi konten kesehatan berupa foto, video, dan poster. 
Peran seorang sarjana kesehatan masyarakat dalam promosi kesehatan yang berbasis media social harus memperhatikan adopsi konsep media social yang telah berhasil di bidang bisnis dan juga menggabungkan media social dengan strategi pemasaran social. Selain itu juga harus memaksimalkan paparan informasi dengan basis bukti yang kuat, dengan mempertimbangkan konten relevan untuk audien yang tepat atau bahkan berbeda serta memperjelas peran professional dalam memfasilitasi media social.

\section{Kesimpulan}

Promosi kesehatan berbasis media social pada kaum millennial merupakan inovasi yang bagus untuk di kembangkan di masyarakat. Umumnya kaum millennial pada saat ini sering mengakses media social dalam kehidupannya. Media yang diakses oleh kaum millennial berupa Facebook, Instagram, Youtube, Twitter, Blog dan lainnya. Media sosial melalui internet memiliki potensi besar untuk melakukan promosi kesehatan dan intervensi kesehatan lainnya, dan lebih mudah untuk menyentuh sasaran pada setiap levelnya. Bukti menunjukkan pemanfaatan media sosial efektif dalam melakukan upaya promosi kesehatan dengan tujuan meningkatkan pemahaman dan memberi dukungan kepada masyarakat untuk berperilaku sehat, namun tidak dapat dipungkiri, dibalik kesuksesan media tersebut terdapat beberapa kelemahan.

\section{Daftar Pustaka}

Kemenkes RI. 2011. Promosi Kesehatan Di Daerah Bermasalah Kesehatan Panduanbagi

Petugas Kesehatan di Puskesmas. Jakarta: Kemenkes RI

Notoatmodjo,S. 2015. Promosi Kesehatan dan Perilaku Kesehatan. PT Rineka Cipta. Jakarta

http://eprints.uad.ac.id/15793/1/Buku\%20Ajar\%20Pengembangan\%20Media\%20Promos i\%20Kesehatan.pdf

Thea, Rahmani. 2016. Penggunaan Media Sosial Sebagai Penguasaan DasarDasarFotografi Ponsel, Universitas Islam Negeri Sunan Kalijaga Yogyakarta 